\title{
OS LUGARES ONDE FOMOS: MEMORIAL DE LIVRE DOCÊNCIA
}

Manoel Fernandes de Sousa Neto

Professor Livre Docente da Universidade de São Paulo manoelfernandes@usp.br

Recebido para publicação em 10/05/2020 e aceito em 01/06/2020

DOI: $10.12957 /$ tamoios.2020.50884

O presente memorial foi defendido em junho de 2019, como parte do processo de avaliação, com vistas a obtenção do título de livre docente na disciplina de História do Pensamento Geográfico do Departamento de Geografia junto à Faculdade de Filosofia, Letras e Ciências Humanas da Universidade de São Paulo.

Queria aqui registrar meus agradecimentos a banca composta por André Roberto Martin (USP-Geografia), Amélia Luisa Damiani (USP-Geografia), Beatriz Picolotto Siqueira Bueno (USP-FAU), Pedro de Almeida Vasconcelos (UFBA) e Antonio Thomaz Junior (UNESP-PP), pela avaliação a um só tempo rigorosa, crítica e propositiva, além de acolhedora e sensível.

Queria ainda agradecer aos amigos que não pouparam esforços na ajuda, sempre solidária, de juntar e organizar a papelada que foi toda posta em meio digital. A nossa gratidão a José Levi Sampaio, Evaldo Maia e Sandra Silva da Universidade Federal do Ceará. A Renato Alves na Universidade Federal da Paraíba. A Charlles da França da Universidade Estadual do Rio de Janeiro. A Silvia Lopes Raimundo da Universidade Federal de São Paulo. A Urbano Nobre Nojosa da PUC São Paulo. A Gilmar Santos, Denis Nogueira e Roger Montemor por tornarem sua casa o centro de operações onde se permitiu reunir a documentação dispersa.

Agradeço ainda aos colegas da Universidade de São Paulo que trabalham nas secretarias da graduação e da pós, pelo sempre presente apoio e incentivo, bem como pela presteza em disponibilizar a documentação ainda ausente: Luciana Ramos, Cristina Paradas, Celito, Rosângela, Cida e Fermino.

Minha gratidão ainda para com meus colegas docentes que tem sido companheiros nas muitas aprendizagens e incentivaram essa pequena aventura acadêmica, com especial atenção para Anselmo Alfredo, Elvio Martins, Fernanda Padovesi, Sandra Lencioni, Marta Inês, Glória Alves, Rita Ariza Cruz e Ricardo Antas Jr.

Aos estudantes da graduação e da pós, ao longo de todo o percurso de treze anos como docente da USP, não há palavras que caibam nos agradecimentos.

Agradeço ainda aos colegas do movimento docente da USP, sempre imprescindíveis para pensar e defender o projeto de universidade pública, gratuita, laica, socialmente referenciada e de qualidade.

Em destaque queria agradecer ainda a Eduardo Dutenkefer que deu vida aos mapas nesse memorial. A sua generosidade, amizade, simpatia, disponibilidade, erudição e bom humor, tornaram mais leve e mais belo este memorial.

Por fim, mas não menos importante, dedico esse memorial a Wilma Lucena, minha companheira, que nas minhas angústias com as linguagens informacionais foi quem montou o texto em sua versão final para apreciação. 


\section{Antes de Dizer Algo: Memorial e Método}

O recurso utilizado por Machado de Assis em Memórias Póstumas de Brás Cubas é, a um só tempo, desconcertante e irônico. Mortos não falam, não narram, não contam histórias, não escrevem livros. Brás Cubas, no entanto, não é um defunto qualquer, mas um defunto-autor. O movimento machadiano permite duas fabulações. Começar a contar os acontecimentos daquele ponto da vida, o dia do próprio funeral, em que não se viverá nada mais além de um enterro pessoal e, em seguida, dizer tudo a partir de uma retrospectiva que dispõe do morto-narrador, evocado como responsável único por todas as más condutas durante a vida que, agora, pode revelar sem risco de punição.

O importante, no entanto, é que Brás Cubas o personagem utilizado por esse escritor mulato, Mestre da Literatura na Periferia do Capitalismo que é Machado, segundo Roberto Schwartz, serve para expor como a sociedade brasileira se ergueu sob o signo da violência e de relações próprias da sociabilidade do capital em um país de capitalismo tardio.

O recurso de método machadiano apresenta muitas possibilidades para uma análise vinculada à lógica dialética. Sugere, em princípio, que histórias individuais não podem ser compreendidas fora das condições de existência em suas múltiplas determinações. Propõe, depois, um movimento que não se encerra com a morte e fala de um presente histórico vivido por aqueles que leem a história de um morto, como se os mortos comandassem a vida dos vivos. Dispõe, ainda, de elementos que açulam as contradições em processo, ao destacar escravizados como o personagem Prudêncio, que carregam consigo o desejo de, imediatamente libertos, se tornarem senhores como o era Brás Cubas.

Imaginamos que a literatura machadiana teria sido para Karl Marx, tão lida quanto aquela produzida por Honoré Balzac. Embora não saibamos se Machado um dia chegou a folhear algumas das obras do autor d'O Capital. O fato é que a ficção, a fabulação, a literatura em seu sentido amplo, baralham com a vida real para nos permitir apropriações críticas do mundo e fabularmos que Machado tenha lido Hegel, Marx, Lukács.

$\mathrm{O}$ memorial que lhes apresentamos segue assim, machadianomarxistamente, alguns princípios de método. A saber:

Pretende apresentar um candidato a Livre Docente da Universidade de São Paulo que, como já dissera João Cabral de Melo Neto sobre o personagem central de Morte e Vida Severina, segue seu próprio enterro e, logo se faz acompanhar na vida, daquelas mortes com as quais convive ao longo de uma existência social e historicamente datada.

Propõe analisar sua trajetória intelectual no interior das mudanças ocorridas no mundo do trabalho e, de modo particular, na faina de trabalhador acadêmico que transitou pela carreira universitária no Brasil em instituições públicas que sofreram diversas transformações, adequações e transições próprias de concepções políticas de educação superior mercantil, Estado Mínimo e regulações liberais.

Visa refletir criticamente sobre a lide intelectual que foi sendo subsumida, nomeadamente após a década derradeira do século passado, àquela aceleração contemporânea de que falava Milton Santos e que põe sob ameaça os homens lentos, a teoria crítica e os saberes inaugurais.

Deriva de um conjunto de escolhas teóricas que não aderiram à virada espacial que veio propor o fim das metanarrativas, a adesão ao discurso pós-moderno e a filiação ideológica ao fim do Estado, da História e dos Territórios.

Encerra como proposição que, embora com finalidades muito bem explicitadas, todo concurso é um momento de exercício intelectual e não um fim em si mesmo, para dizer que o diálogo com os pares da banca examinadora não se dá em torno de títulos 
formais, mas de proposições intelectuais e, se reconhece os limites, imagina ampliar suas possibilidades.

\section{Palavras Iniciais ou de um Manifesto Jaboticabano}

Sabendo que as memórias pessoais não podem ser vividas na ausência das relações sociais e históricas que lhes garantem existência é, por esse mesmo motivo, que não há trabalho intelectual dissociado - ainda que estude a primavera dos tempos - da presença do mundo e das contradições que lhe pariram. Viver é por isso também engravidar, mesmo diante da barbárie, o ainda não vivido.

Um Memorial para Defesa de Livre Docência na Universidade de São Paulo, não pode olvidar o que isso significa como parte da história social da inteligência brasileira, nem muito menos transcender o momento de contrarreformas "just in time" a que são conduzidas as universidades públicas no mundo e, em particular no Brasil, capitaneadas por razões de mercado e pelo fetiche de uma internacionalização subordinada e subsumida à mera racionalidade financeira.

Os memoriais, se servem para justificar os méritos de um indivíduo na busca por acessar um título na carreira, têm também o papel de manifestar o sentimento coletivo que partilham esses mesmos indivíduos e as contendas travadas pelas quais se dedicaram.

Memoriais, para fins acadêmicos, necessitam informar o lugar que vimos ocupando nos mais diferentes momento da luta política dentro e fora da Universidade, para evitar dúvidas quando nos perguntarem os estudantes de que lado estávamos quando houve ditaduras, impeachment, criminalizações dos movimentos sociais, retiradas de direitos docentes e demissões em massa de funcionários técnico-administrativos para ajustar contas.

Um memorial deve servir, assim, para dizer daqueles momentos em que as reitorias uspianas começaram a tratar as diferenças de pensamento como um caso de polícia, como naquele ano inaugural de 2007 em que nos tornamos Professores Doutores em Regime de Dedicação Integral de Docência e Pesquisa (RDIDP) no Departamento de Geografia da Faculdade de Filosofia, Letras e Ciências Humanas da Universidade de São Paulo para logo nos depararmos com a autorização realizada pelo Conselho Universitário (CO) à Reitoria para vermos a entrada da polícia e da violência militar na cidade universitária.

O nosso ingresso na Universidade de São Paulo em 20 de março de 2007, se deu em meio à crise que se instalou com a publicação do Decreto $n^{\circ} 51.461$ de $1^{\circ}$ de janeiro daquele ano lavrado pela pena do então Governador José Serra. Conhecido como Decreto Declaratório, o mesmo retirava das Universidades Públicas paulistas sua autonomia financeira e repassava para uma Secretaria de Ensino Superior o papel de auditar e, logo, gerir os recursos conquistados junto à quota de aproximadamente $9 \%$ do ICMS que é dividida entre USP, UNICAMP e UNESP. O Decreto $\mathrm{n}^{\circ}$ 51.461, na prática, previa que estes recursos seriam contingenciados e as decisões de como usá-los seriam transferidas para a Secretária de Educação Superior.

Após várias tratativas, muita grita contra o referido decreto declaratório e negociações que não resultariam em nada, ainda no dia 03 de Maio de 2007 os estudantes ocuparam a Reitoria da Universidade de São Paulo e alguns dias depois funcionários e professores entraram em greve (Figura 01) forçando o Governador José Serra a rever os termos que anunciavam a retirada da autonomia universitária e o decreto, enfim, virasse letra morta. Porém, uma prática de violência institucionalizada se instalaria de modo inaugural com o ingresso da Polícia Militar para reintegração de posse do prédio da Reitoria para, nos anos seguintes, passar a presença e a violência da polícia militar na 
cidade universitária a ser algo tão recorrente como a criminalização, perseguição e demissão ou exclusão de dirigentes sindicais e estudantis.

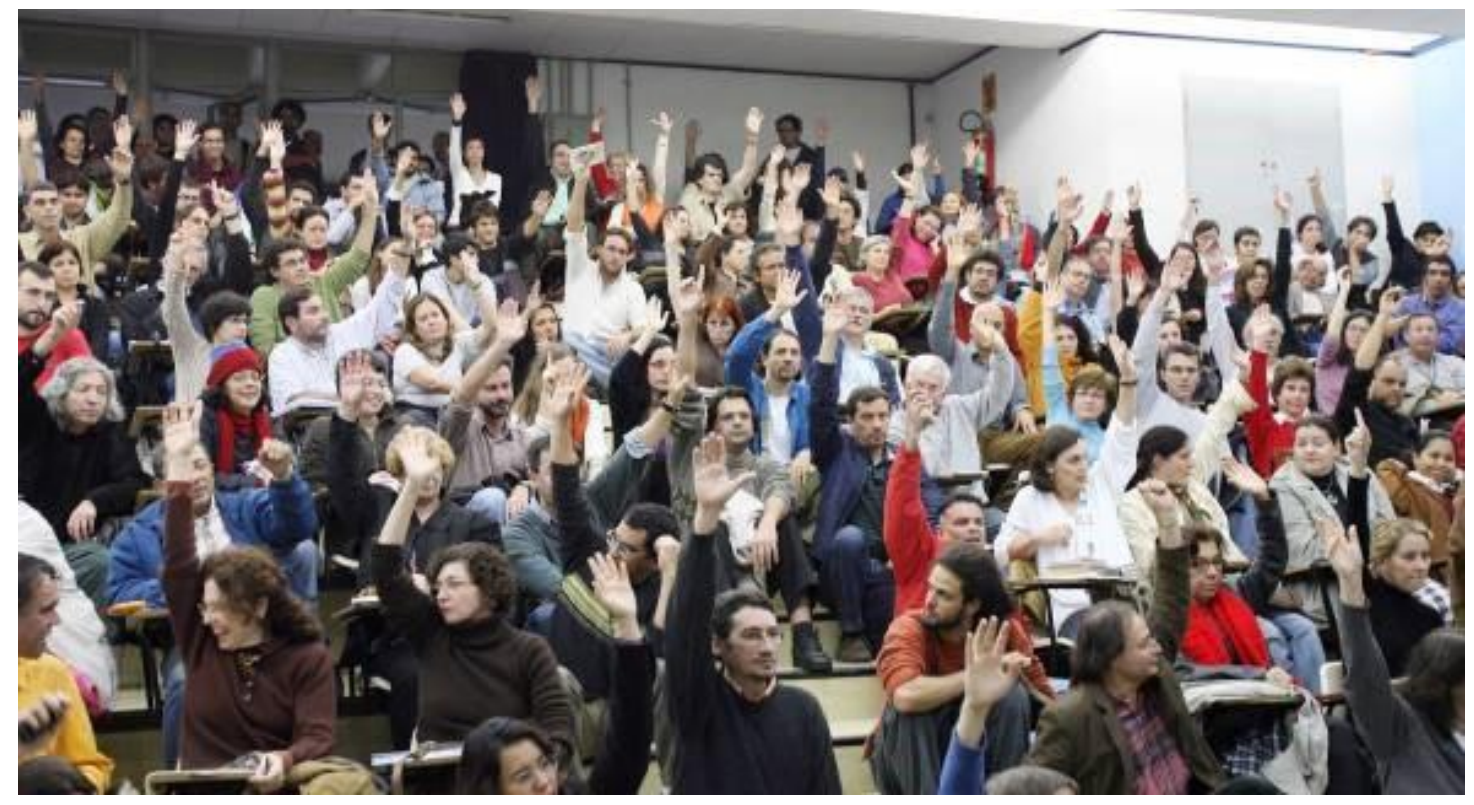

Figura 01: "Professores da USP decretam greve por tempo indeterminado", 23 de maio de 2007. Foto: Moacyr Lopes Jr./FSP

O engajamento com a greve, com a luta e com aquela universidade pública que era a USP em que escolhemos trabalhar, foi imediata.

A Universidade de São Paulo havia nos atraído quando fôramos estudantes de mestrado (1992-1997) e doutorado (2000-2004) e havíamos aí encontrado aquele ambiente acadêmico das aulas com intelectuais da estatura de Alfredo Bosi e Milton Santos, ao mesmo tempo que com os grupos de estudos fluíamos em seu ritmo semanal e estávamos presentes nos muitos seminários, colóquios e congressos como O Novo Mapa do Mundo (1992) que reuniu geógrafos/as e não-geógrafos/as dos quatro cantos do planeta.

Outra coisa que muito nos atraíra e que desconhecíamos como prática educativa, eram as plenárias realizadas pela comunidade do Departamento de Geografia da USP. Ali vislumbramos um outro fazer social da universidade e da construção do conhecimento, na medida em que todos podiam falar fossem estudantes, professores ou técnicos e as deliberações, embora meramente consultivas, tivessem um caráter universal.

Cruzar os umbrais da Universidade de São Paulo como professor quinze anos depois de tê-la adentrado como estudante de mestrado, sabendo inclusive que uma daquelas vagas de claro ${ }^{1}$ docente em que entramos havia sido parte das conquista da greve de 2000, faziam daquele ano de 2007 uma espécie de iniciação de sangue, um batismo de fogo, um poema em redondilha recitado em praça pública.

É não sem razões que nos anos que se seguiram nos tornamos atuantes no movimento docente e fomos eleitos para representar os colegas doutores no colegiado da Congregação da Faculdade de Filosofia, Letras e Ciências Humanas (FFLCH) no Biênio 2009-201 e ato contínuo também nos tornamos representantes dos doutores no Conselho Universitário (CO) no mesmo interregno, para vivenciarmos a transição entre as Reitorias da Professora Suely Vilela e o Professor João Grandino Rodas, bem como a consequente mudança na carreira docente. Mudança na carreira docente à qual nos opomos por compreendermos que a criação de níveis intermediários entre doutores e entre associados 
fortalecia a burocracia meritocrática dos titulares e, ao mesmo tempo que confundia carreira com ganhos salariais imediatos, justificava o achatamento dos ganhos e criava as condições para esvaziar a autonomia intelectual docente ao submetê-la a uma lógica produtivista.

Aquilo que denunciamos com muitos outros colegas docentes foi sendo aplicado ao longo dos anos que sucederam a aprovação da nova carreira em 2011 e, ato contínuo, a corrosão e destruição da autonomia docente na USP, bem como o seu caráter de universalidade do conhecimento e da diversidade das formas de produzir saber, foram sendo erodidas e subordinadas à lógicas de controle do trabalho intelectual expressas em normas que passaram a prorrogar a aprovação ou simplesmente reprovar os estágios probatórios dos docentes ingressos após 2008.

A ampliação do interregno de realização do estágio probatório docente ou de sua reprovação tornou-se fenômeno comum a partir de 2014 e exigiu que vários departamentos da Faculdade de Filosofia, Letras e Ciências Humanas (FFLCH) se posicionassem contra este ataque que colocou sob suspeição a qualidade do trabalho realizado pelos docentes, promovendo a ameaça de piora nas condições laborais e consequente redução salarial ao pôr em xeque sua permanência no regime de dedicação exclusiva (RDIDP) essa espécie de "jaboticaba brasileira", para lembrar as colonizadas palavras do Reitor à época o médico Marco Antonio Zago².

O mesmo reitor Marco Antonio Zago que fez história ao oferecer reajuste zero em seu primeiro ano como dirigente da universidade e ao longo de seu mandato buscou fechar a Creche-Escola da Faculdade de Educação e desmontar o Hospital Universitário, bem como contratou a consultoria privada $\mathrm{McKinsey}^{3}$ para propor modelo de gestão à uma universidade pública como a USP e aprovou a atual política de avaliação, pari passu, criando um novo estatuto docente em 08 de novembro de 2016. Naquele mesmo 2016, diga-se de passagem, de muitos golpes. Reitor eleito sob o discurso do diálogo que nunca realizou, promoveu ainda com o auxílio violentíssimo da polícia militar e sua tropa de choque a aprovação do limite de gastos com pessoal naquele Conselho Universitário constrangido e constrangedor do dia 13 de março de $2017^{4}$.

Agora vivenciamos na carne o significado de uma carreira que passa a ser gerenciada por metas de mercado e apalpamos o tempo em que os novos colegas, aqueles que dividem os mesmos ambientes e tarefas, já não mais se aposentarão como nós e não gozaram de direitos dos quais um dia pudemos usufruir.

A aprovação e, agora, implementação da avaliação de institutos e unidades, departamentos e docentes põe sobre todos uma espada de Dâmocles e arrancam do cotidiano da Universidade de São Paulo o seu caráter republicano, o seu tempo da diversidade lenta, a sua potência de embora ter sido criada para poucos estar sempre aberta para muitos.

A carreira docente passa, inexoravelmente, a nosso ver, pelos fóruns, conselhos e comissões e foi por esse motivo que depois de um pós-doutorado na Universidade do Porto entre 2012 e 2013, retornamos à Congregação da FFLCH entre 2013 e 2015 e passamos a integrar, ainda que na condição de suplentes, o Colegiado do Departamento de Geografia desde dezembro de 2016.

Por outro lado, é indispensável lembrar que a experiência de maior acolhimento e aprendizagem nos anos iniciais como Professor do Departamento de Geografia da Universidade de São Paulo foram vivenciados ao lado das colegas Sueli Furlan, Glória Alves e Fernanda Padovesi com quem compúnhamos a Comissão e Ensino de Geografia. Foi com essas professoras e por partilhar tantas aprendizagens que permanecemos na Comissão de Ensino por mais de quatro anos entre 2007 e 2012. 
A companhia generosa da Professora Sueli Furlan segue em outra frente desde que assumimos a direção da Associação Nacional de Pós-Graduação e Pesquisa em Geografia (ANPEGE) para o biênio 2018-2019 e onde fomos parar graças a uma decisão política do colegiado da Pós-Graduação em Geografia Humana diante das políticas de avaliação da CAPES e seu caráter homogeneizador, burocrático e produtivista. Em certo sentido, significava agora representar o mesmo coletivo de docentes que, majoritariamente e durante a labuta cotidiana, esteve presente nas greves históricas e na defesa da universidade pública.

No entanto, em meio a decepção com os rumos que a carreira docente tomaram na USP, acompanhado dos baixos salários dessa instituição em comparação às suas congêneres no Brasil e dos altos custos, emocionais e financeiros, para viver em uma metrópole como São Paulo, resolvemos à exemplo de muitos outros colegas que têm deixado a USP, prestar concurso de provas e títulos para o cargo de Professor Titular Livre em Geografia Humana do Campus de Pontal da Universidade Federal de Uberlândia (UFU) onde fomos aprovados e nomeados.

A permanência na Universidade de São Paulo se deve há muitas coisas e uma delas é a coragem, a solidariedade e a firmeza na defesa da universidade pública que têm a maioria daquelas e daqueles que fazem o Departamento de Geografia e a Faculdade de Filosofia, Letras e Ciências Humanas da USP. Um intelectual coletivo com o qual vale a pena estar mesmo nas piores e mais difíceis batalhas.

Ao ficarmos, por outro lado, tínhamos a tarefa de permanecermos distintamente e passamos a ponderar sobre uma decisão antiga e uma escolha que tem sua datação naquele ano em que foi aprovada a atual carreira docente. A decisão que tivemos, mantivemos e pela qual pagamos o preço de permanecer com o salário rebaixado foi o de não nos submetermos à nenhuma forma de ascensão horizontal e, por isso mesmo, ainda que em 2012 pudéssemos ter "ascendido" à condição de Professor Doutor II, não o fizemos e não temos a menor pretensão de fazê-lo.

A decisão de concorrer à Livre Docência na Disciplina de História do Pensamento Geográfico é acadêmica. A decisão de defender a Livre Docência na Universidade de São Paulo é, nomeadamente, política.

A Universidade de São Paulo precisa de intelectuais como nós para não se tornar uma universidade qualquer, dessas em que mal se pode provar o sabor que as jaboticabas têm.

Jabotiquemos, livredocentemente, juntos.

\section{Os Processos de Formação: olhando em volta enquanto se retorna aos começos}

O Professor Doutor João Carlos Garcia sabe como viajar com mapas de todos os tipos e sobre como fazê-los dialogar com música, literatura, cinema, objetos cotidianos, livros. Ao encontrá-lo pudemos ver o quanto a cartografia produz textos fabulosos e nos permite com vários outros documentos históricos, remontar processos de uma maneira absolutamente fascinante e navegar entre políticas de fronteira e história da ciência.

Em meio aos passos do erudito João Carlos Garcia, pudemos nos fazer acompanhar dele em um pós-doutorado sobre O Convênio Luso-Brasileiro de 1867: coleções, mapas e instituições, realizado entre as cidades de Lisboa e do Porto, já que na primeira estavam os arquivos e na segunda os encontros de orientação, o vínculo institucional e as atividades acadêmicas.

Foi com o pós-doutorado realizado naquele ano acadêmico europeu entre Setembro de 2012 e Julho de 2013 que se alargaram sobremodo nossas incursões pela literatura sobre História da Cartografia e Cartografia Histórica, lendo autores como John 
Brian Harley, Edney Mathew e Mark Momonier para falar apenas de alguns. Viajando para participar de eventos importantes em Helsink, na Finlândia. Aprendendo a apreciar obras de arte e pintores como Jeromimus Bosh e William Turner. Mas, sobretudo, por captar este movimento de estar envolto naquela atmosfera em que se cultiva um olhar mais atento e amplo sobre as formas de produzir discursos acerca do mundo.

E como conheci João Carlos Garcia? O conheci quando escrevia o último capítulo de minha tese doutoral Planos Para o Império: os planos de viação do Segundo Reinado (1869-1889). A tese, ao longo dos temas que tratava, obrigatoriamente cruzou os caminhos da história da cartografia e escrevemos para aquele desconhecido professor português para saber se nos poderia ajudar. A resposta lusitana foi rápida e deu pistas importantes que iam de temas referentes a como tratar de coleções cartográficas a vislumbrar a circulação dos mapas e suas diversas apropriações. $\mathrm{O}$ fato é que quando nos tornamos doutores em 2004, o João Carlos já se havia transformado um amigo de longa jornada e um intelectual de grande contributo para nossas reflexões.

O doutorado ratificou várias das nossas opções intelectuais. A primeira delas a de manter o orientador do mestrado, Professor Doutor Antonio Carlos Robert Moraes. A segunda de continuar a investigar o período de meados do século XIX, onde o Brasil Império vivia de múltiplas transições. A terceira de fazer um texto acadêmico que fosse literário e ao mesmo tempo dialogasse com várias áreas das ciências humanas.

A orientação segura e toda a formação intelectual densa que pudemos obter vieram das conversas, polêmicas, debates e aprendizagens diversas com aquele que acabou se tornando colega na USP anos depois e um amigo mais que dileto. O Tonico, como conhecíamos um dos maiores teóricos da Geografia no Brasil das últimas décadas, foi aquele que nos conduziu a tecer uma dissertação intitulada Senador Pompeu: um geógrafo do poder no Império do Brasil, nos permitindo aceder à condição de titulado a Mestre em Geografia Humana no ano de 1997.

A dissertação sobre um personagem que teve boa parte de sua atuação política durante a segunda metade do século XIX, serviu para que se soldassem aspectos de uma formação que transitava pela literatura, história, sociologia do conhecimento, história da ciência, teoria política, filosofia, história da educação e enfim nos fez deslindar muitas tessituras. Um diálogo tão profícuo e tão profundo cremos não se poderia dar fora daquilo que foram duas das principais chaves de entendimento propostas por Antonio Carlos Robert Moraes para o Brasil. A primeira delas o do papel das ideologias geográficas na conformação de discursos competentes para naturalizar processos sociais. A segunda, a da formação territorial em um País de capitalismo tardio como o Brasil e as singularidades desse processo.

É possível dizer que aquilo formulável hoje por nós como uma história da geografia na geografia histórica do capitalismo nasceu desse longo convívio com Antonio Carlos Robert Moraes, amigo a quem todas as homenagens serão sempre pequenas.

O encontro com o Tonico veio depois da graduação na Universidade Federal do Ceará e em função da indicação de alguns de nossos professores como José da Silva e Tércia Cavalvante. Foi sob a orientação de Tércia Cavalcante, mestra de grande sensibilidade e profundo conhecimento, que pudemos realizar estudos sobre o Uso da Poesia no Ensino da Geografia para defender uma monografia que nos levou a obtenção do título de Bacharel em 1993.

A opção por nos tornarmos primeiro licenciados se deve ao fato de ter vivido em paralelo à nossa formação acadêmica universitária, a experiência de sermos professor em escolas do ensino fundamental e médio. Por esse motivo, embora tenhamos nos tornado Licenciados em Geografia já em 1992, já dávamos aulas em 
escolas da periferia de Fortaleza desde o ano de ingresso ocorrido em 1988 na Universidade Federal do Ceará (UFC). E foi na UFC que, para além da sala de aula e do forte envolvimento com o movimento estudantil, tendo em vista que fomos do Centro Acadêmico Amélia Alba(1988/1989), do DCE-UFC (1989/1990), da Executiva Nacional de Estudantes (1990/1991) e da diretoria da UNE (1991/1992); pudemos realizar uma monitoria em Introdução à Ciência Geográfica e Geografia Agrária, no período de março a dezembro de 1990.

Ainda muito sem saber, aquela monitoria em Introdução à Geografia marcaria uma escolha para toda vida e se estenderia de maneira indelével pela nossa formação: a preocupação com as questões de teoria, método e aprendizagem da geografia mediadas pelas investigações em história da geografia. É quiçá, por esse percurso que pudemos ir nos formando ao contribuir com a formação de outros e outras estudantes, como veremos logo a seguir.

\section{Travessias em Inventário: vinte e cinco anos de docência universitária}

As águas que cruzamos já não são as mesmas e nós, ao certo, não sabemos bem aquilo que nos tornamos ao transpor a liquidez das suas linhas. A docência foi e é para nós, anunciamos logo, um exercício de via dupla, em que vamos sendo aquilo que nos faz ser.

Uma asserção inicial importante é que pesquisa, ensino e extensão sempre estiveram compreendidas como dentro de atividades relativas à docência e assim quando falávamos, escrevíamos, pesquisávamos sempre imaginávamos como as nossas palavras e gestos e voz e alumbramentos iam tocar o coração dos outros.

Ainda a altura dos vinte e quatro anos de idade, recém-formados fizemos vários concursos públicos para entrar na vida docente. O primeiro para a Secretaria de Educação do Estado do Ceará, com a obtenção de uma das doze vagas sagradas em meio a mais de seiscentos candidatos. O segundo concurso que fizemos, ainda em fins de abril de 1992, foi para Professor Auxiliar de Geografia Humana na UFBA, onde obtivemos um honroso terceiro lugar e a certeza de que deveríamos seguir a carreira acadêmica nessa área do conhecimento.

Essas duas tentativas iniciais de entrar na docência em caráter público revelam aspectos importantes do início da nossa vida profissional. Abrimos mão de sermos professores do Estado do Ceará em nível médio porque resolvemos investir no mestrado em São Paulo e na USP, ainda que sem bolsa no momento inicial. A outra é que a conjuntura da época permitia que se ingressasse na universidade pública para o exercício da docência apenas com graduação e se construísse a carreira e formação de maneira paralela, sendo que a carreira começava com a condição de Professor Auxiliar.

Quando ainda fazíamos as disciplinas do Mestrado em Geografia Humana na USP e ávidos por adentrar a Universidade Pública e os portais da docência fizemos, em paralelo, três concursos públicos na UFPB em uma mesma semana. Obtivemos assim aprovação para Professor Auxiliar da UFPB sendo um $1^{\circ}$ lugar em Geografia Humana, um $2^{\circ}$ lugar em Metodologia e Aplicação e um $5^{\circ}$ lugar em Geografia Regional naquele outubro de 1992.

Em 03 de Maio de 1993, com 25 anos de idade, assumimos a vaga de Professor Auxiliar em Geografia Humana da UFPB, tendo permanecido nessa Universidade até 1998, por exatos 05 anos, 06 meses e 23 dias e ai ministrado muitas disciplinas, mas especialmente as disciplinas de Introdução a Geografia e Geografia Humana $\boldsymbol{e}$ Econômica do Brasil. 
Uma vez mais voltávamos a nos encontrar com Introdução a Geografia, disciplina com a qual havíamos trabalhado na monitoria como estudantes de Graduação na Universidade Federal do Ceará e, dentre às escolhas, como veremos, esta foi se consolidando como campo de investigação, atuação e formação intelectual.

Bom, mas quando chegávamos a meados de 1998, resolvemos retornar a Fortalezae a UFC, ao realizar Concurso de Provas e Títulos para Professor Assistente em Geografia Humana. Conseguimos uma aprovação em $1^{\circ}$ lugar e nomeação em 7 de Agosto de 1998 e nos tornamos docentes da Universidade onde havíamos nos formado e voltávamos para casa acadêmica e dos pais.

O exercício da docência na UFC se deu entre aquele setembro de 1998 e março de 2007 e ali também ministramos na Graduação em Geografia e em duas PósGraduações da Universidade Federal do Ceará o Programa de Desenvolvimento e Meio Ambiente (PRODEMA) e o Programa de Educação Brasileira da Faculdade de Educação (PEB) disciplinas vinculadas à formação territorial do Brasil, teorias sobre moderno e pós-moderno e geografia humana e econômica, quando então mudamos nossa residência intelectual para USP e para a megalópole de São Paulo.

A Universidade Federal do Ceará foi o lugar de muitos reencontros, mas de diversos desencontros também. Ali ministramos a disciplina de Introdução a Geografia apenas uma vez no ano de 1999 e acabamos por ministrar disciplinas nos cursos de Ciências Sociais e História, a mesma Geografia Humana e Econômica que tanto aprendemos a amar, em função do amplo diálogo com outras áreas do conhecimento e epistemologias das ciências humanas. A Universidade Federal do Ceará (UFC) foi aquele lugar para o qual se deveria ter voltado para encerrar ciclos e ali pudemos trabalhar durante os anos de 1998 e 2007, quando então acabamos indo dar com os costados na Universidade de São Paulo.

Todas as travessias desde a formação ao exercício profissional entre a docência em três universidades públicas e os cursos de formação intelectual, nas diversas cidades brasileiras e em Portugal podem ser expressas no Mapa Percursos.

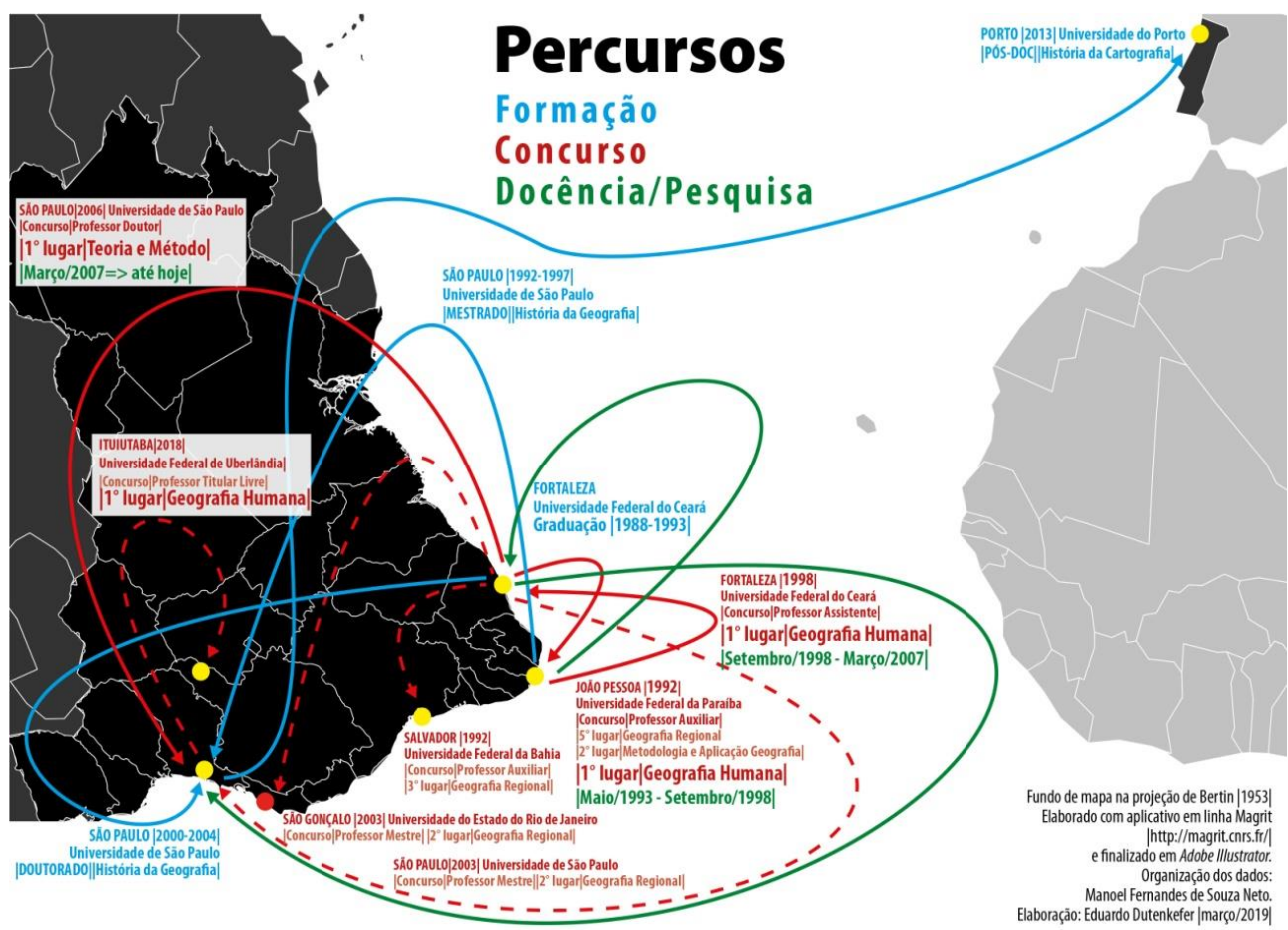

Figura 02: "Mapa Percursos - Formação, Concursos, docência/pesquisa". Elaboração: Eduardo Dutenkefer. Organização dos dados: Manoel Fernandes de Sousa Neto. 
Antes e depois de entrar na Universidade de São Paulo viajei por muitos lugares proferindo conferências e palestras, participando de eventos dentro e fora do Brasil, indo das grandes metrópoles às pequenas cidades, para falar a pares de longa formação e a estudantes que estavam no começo das suas lides como geógrafos/as.

A trajetória de lugares vários e de encontros muitos com pessoas que foram compondo a história da nossa carreira acadêmica e intelectual, estão sintetizadas em um mapa que ressalta os muitos endereços geográficos em que estivemos, mas ressaltam nos Mapas "Eventos" esse movimento de circular pelo mundo em torno dos temas de investigação e docência com os quais nos envolvemos.

Os Mapas "Eventos" já destacam bem os temas principais (Figura 03) com os quais lidamos ao longo da nossa história profissional.

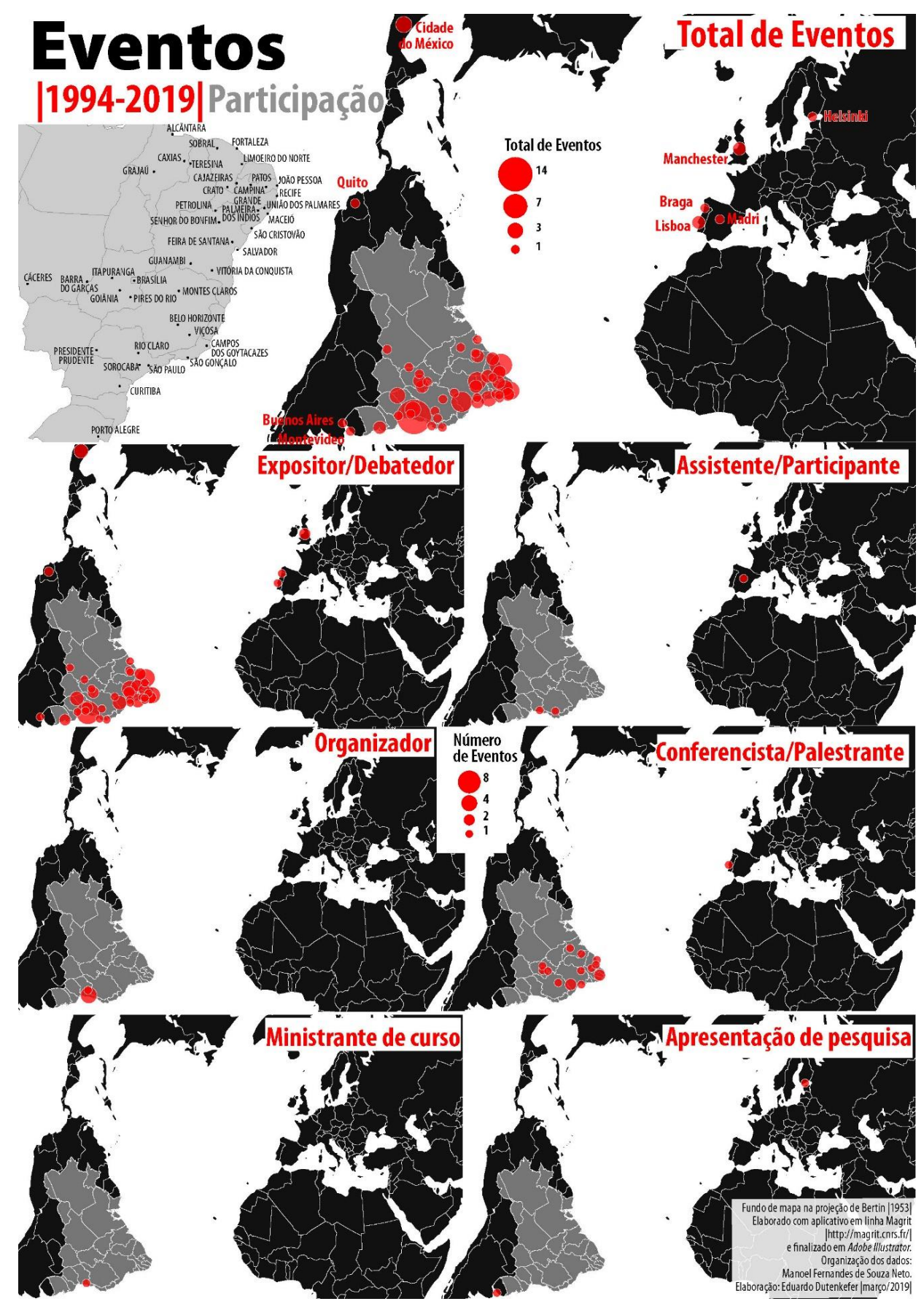

Figura 03: "Mapa de Participação em Eventos". Elaboração: Eduardo Dutenkefer. Organização dos dados: Manoel Fernandes de Sousa Neto. 


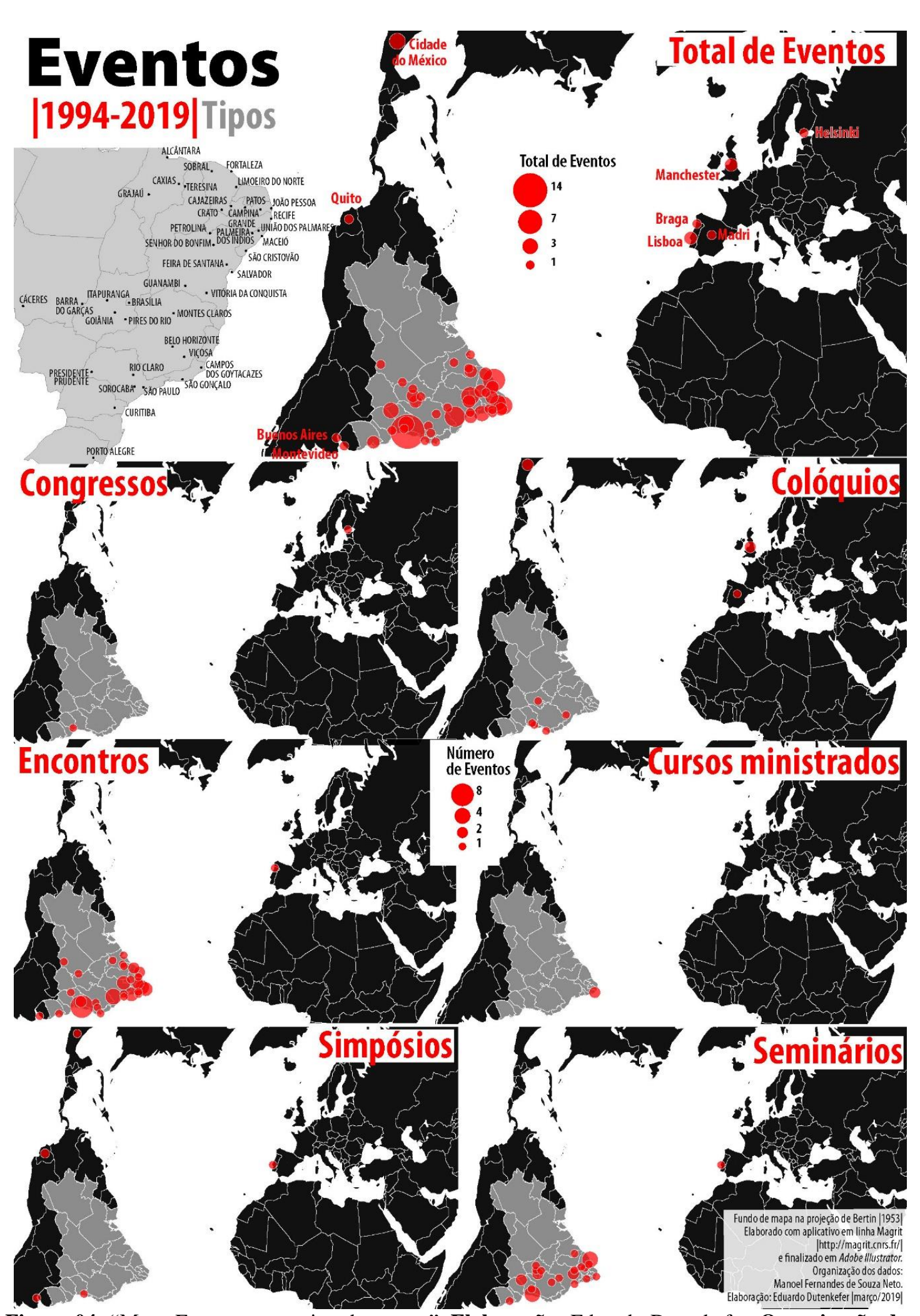

Figura 04: "Mapa Eventos - por tipo de evento". Elaboração: Eduardo Dutenkefer. Organização dos dados: Manoel Fernandes de Sousa Neto. 


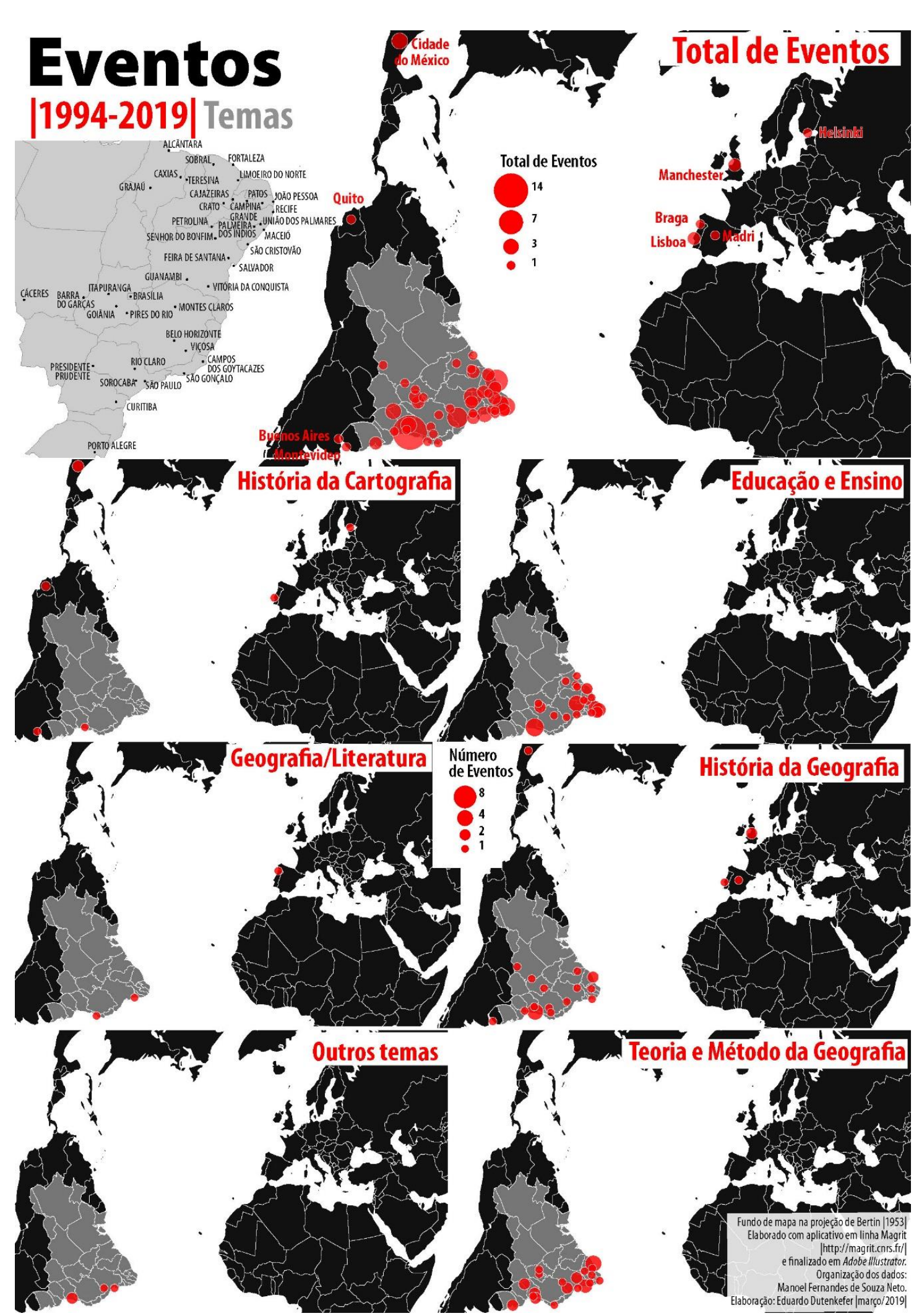

Figura 05: "Mapa Eventos - por temas dos eventos". Elaboração: Eduardo Dutenkefer. Organização dos dados: Manoel Fernandes de Sousa Neto.

Os temas são 1) História da Cartografia e Cartografia Histórica; 2) História da Geografia e Geografia Histórica; 3) Educação, História das Disciplinas Escolares e Ensino de Geografia. 
Em História da Cartografia e Cartografia Histórica pudemos participar com comunicação oral, ainda em 2018 na cidade de Quito do $7^{\mathbf{o}}$ SIAHC (Simpósio Iberoamericano de História da Cartografia), evento criado pelas investigadoras argentinas Carla Lois e Perla Zusman em 2006. Este evento que ganhou dimensão internacional teve sua terceira edição realizada em São Paulo, na USP e participamos dele como organizadores e compondo a comissão científica, já que havíamos estado ainda em suas primeiras edições apresentando comunicações orais em Buenos Aires (2006) e na Cidade do México em (2008). A História da Cartografia, onde acabamos indo realizar o pós-doutorado, também possibilitou que apresentássemos com João Carlos Garcia, em Helsink em julho de 2013, na $25^{\circ}$ Conferência sobre a História da Cartografia trabalho intitulado Portuguese and Brazilian Maps at the Centennial Exhibition in Philadelphia, 1876 .

Dentre os temas da História da Cartografia publicamos trabalhos que resultaram de apreciações muito sintéticas sobre as pesquisas que realizamos. $\mathrm{O}$ artigo publicado em 2014 na Revista Tamoios, intitulado O Convênio Luso-Brasileiro de 1867: coleções, mapas $\boldsymbol{e}$ instituições é parte das nossas investigações realizadas no pós-doutorado e trata de como o convênio serviu para estabelecer duas grandes mapotecas, sendo uma delas a do Itamaraty no Brasil que tem excelente acervo e começou com doação realizada pelo diplomata do Império do Brasil, Duarte da Ponte Ribeiro.

Ainda sobre História da Cartografia publicamos dois trabalhos que vieram a luz como capítulos de livro no México. O primeiro deles A Comissão de Triangulação do Município da Corte (1868-1878) organizado por Hector Mendonza Vargas e Carla Lois, no livro Historia de la Cartografia de Iberoamerica de 2009, trata de como o projeto de triangulação que envolvia todo o território estatal do Brasil monárquico, acabou sendo realizado de maneira minuciosa apenas no Município Neutro da Corte, o Rio de Janeiro; e terminou com suas mais de 200 folhas de 1:1.000, consubstanciando um projeto que visava contribuir para diversas políticas que iam do fisco à administração urbana. $\mathrm{O}$ segundo capítulo de livro veio a luz em 2007, escrito à seis mãos, foi realizado em coautoria com Sergio Nunes Pereira e Hector Mendonza Vargas El Mapa Nacional de México y Brasil, 1821-1946 e publicado em livro intitulado La Intergración del Território en una idea de Estado, México y Brasil, 1821-1946, para tratar de como houve similaridades e diferenças nas formas como os mapas nacionais, em diversos momentos históricos desses dois países foi construído por engenheiros-geógrafos e a partir de recursos técnicos comuns utilizados à época, para fins diversos como o controle das fronteiras.

A história da cartografia e cartografia histórica, nascida ainda de estudos de mapas sobre o Brasil à época do doutorado, acabaram por se tornar um dos principais temas de pesquisa e o passamos a ver como essencial à compreensão da história da geografia e da geografia histórica, tema que ocupou boa parte da nossa trajetória intelectual.

Em História da Geografia e Geografia Histórica participamos do $\boldsymbol{V}$ Encontro Nacional de História do Pensamento Geográfico e III Encontro Nacional de Geografia Histórica ocorrido entre os dias 10 e 14 de dezembro de 2018 em Viçosa/MG na mesa redonda Perspectivas Teóricas e Representações Territoriais e já havíamos estado no $\boldsymbol{I V}$ Encontro Nacional de História do Pensamento Geográfico e II Encontro Nacional de Geografia Histórica realizado em 2016 de 05 a 10 de dezembro em Belo Horizonte em mesa redonda intitulada Singularidades e Trajetórias do Pensar/Fazer Geográfico.

O Evento que se realiza desde 1999, quando pudemos ser parte daquele grupo de jovens organizadores do I Encontro Nacional de História do Pensamento Geográfico ocorrido em Rio Claro/SP, contou conosco na organização e participação da comissão 
científica também do II Encontro de História do Pensamento Geográfico realizado dez anos depois em 2009 na Universidade de São Paulo. Em nível internacional pudemos ainda participar de eventos como aquele que se deu em Manchester/UK, organizado pela Comissão de História da Geografia da UGI em sessão que se deu no interior do Congresso Internacional de História da Ciência, Tecnologia e Medicina, apresentando um paper e sendo comentador em uma sessão sobre Educação Geográfica e Conhecimento em Julho de 2013.

Em havendo uma área no Brasil em que se pode dizer que tivemos uma efetiva contribuição para formação de um campo de investigação, esta área é, sem dúvida, a de História do Pensamento Geográfico e História da Geografia.

Para além dos eventos mencionados vale a pena destacar o nosso envolvimento com Sérgio Nunes, Alexandrina Luz, Genylton Rocha, Rita Souza, Silvia Lopes e Leticia Parente na criação da Revista Terra Brasilis em 2000 da qual participamos como editores e onde pude publicar dois artigos. O primeiro sobre geografia escolar intitulava-se $\boldsymbol{O}$ Compêndio de Geographia Geral e em Especial do Brasil (2000) e o segundo discutia, que discutia questões de método em História da Geografia, foi nomeado As Outras Histórias ou da Necessidade Delas (2001) e versava exatamente sobre a importância do trabalho com a documentação de arquivo, propondo que a pequena história deveria se soldar à grande história.

Estivemos com os demais editores da Terra Brasilis até seu nono e último número impresso, em 2005. Voltamos a ser editores da Terra Brasilis quando ela virou digital e Nova Série em 2012 e tivemos a felicidade de escrever sua apresentação naquele momento A Terra Brasilis de Volta ao Mapa.

O retorno da Terra Brasilis ao mapa da história da geografia no Brasil, se deu ainda por outra iniciativa da qual participamos, a criação da Rede Brasileira de História da Geografia e GeografiaHistórica ocorrida em 2010. Hoje se pode falar que este campo está consolidado no Brasil e que o Brasil adquiriu relevante reconhecimento nessa área em todo mundo.

Em parte já havíamos expresso o significado das primeiras tentativas de consolidar este campo de investigação no Brasil e sobre isso publicamos uma nota na Revista InforGeo da Associação Portuguesa de Geógrafos, em 2004 intitulada Por Uma História do Pensamento Geográfico no Brasil..

O último dos livros que publicamos, Um Geógrafo do Poder no Império do Brasil, dormitou como dissertação durante vinte e um anos, para ser publicado agora em 2018, ano em que Thomas Pompeu de Sousa Brasil completaria duzentos anos se vivo fosse e assim resolvemos tirar o texto, laureado com uma menção honrosa pela Fundação Joaquim Nabuco em 1997, para agora ocupar outro vaso de páginas na forma de livro impresso.

O livro trata de como um personagem se vincula ao poder através dos conhecimentos geográficos que mobiliza para a escola, para o planejamento, para as políticas contra a secae para invenção desse aparente fenômeno climático. O período é o da segunda metade dos oitocentos e revela a indispensabilidade da geografia para as artes da política em um país de dimensões continentais.

Outro livro, agora de 2012 e resultado de nossa tese doutoral, publicado pela Editora Alameda, com financiamento da FAPESP, foi o livro Planos Para o Império: os planos de viação do Segundo Reinado (1869-1889). A reflexão fundamental de que trata é como a geografia foi feita por não-geógrafos a partir de engenharias civis e militares que pensaram diversas questões relativas à construção do Estado Territorial e da Nação, dentre elas os processo de integração das diferente latitudes e longitudes desse vasto território. 
Ambos os livros são resultado de pesquisas sobre o Brasil Império, tratando de personagens que fizeram a geografia em um país que a vetusta historiografia da ciência e da própria geografia nomeou como período sem cientistas ou ausente de geógrafos. Este tema foi por mim largamente tratado e objeto de crítica em dois artigos, já antigos, publicados na forma impressa em 2000 e 2001, depois em 2015 na forma on-line, respectivamente na Revista Terra Livre, são eles A Ciência Geográfica e a Construção do Brasil e Geografia nos Trópicos: memórias dos náufragos de uma jangada de pedras?

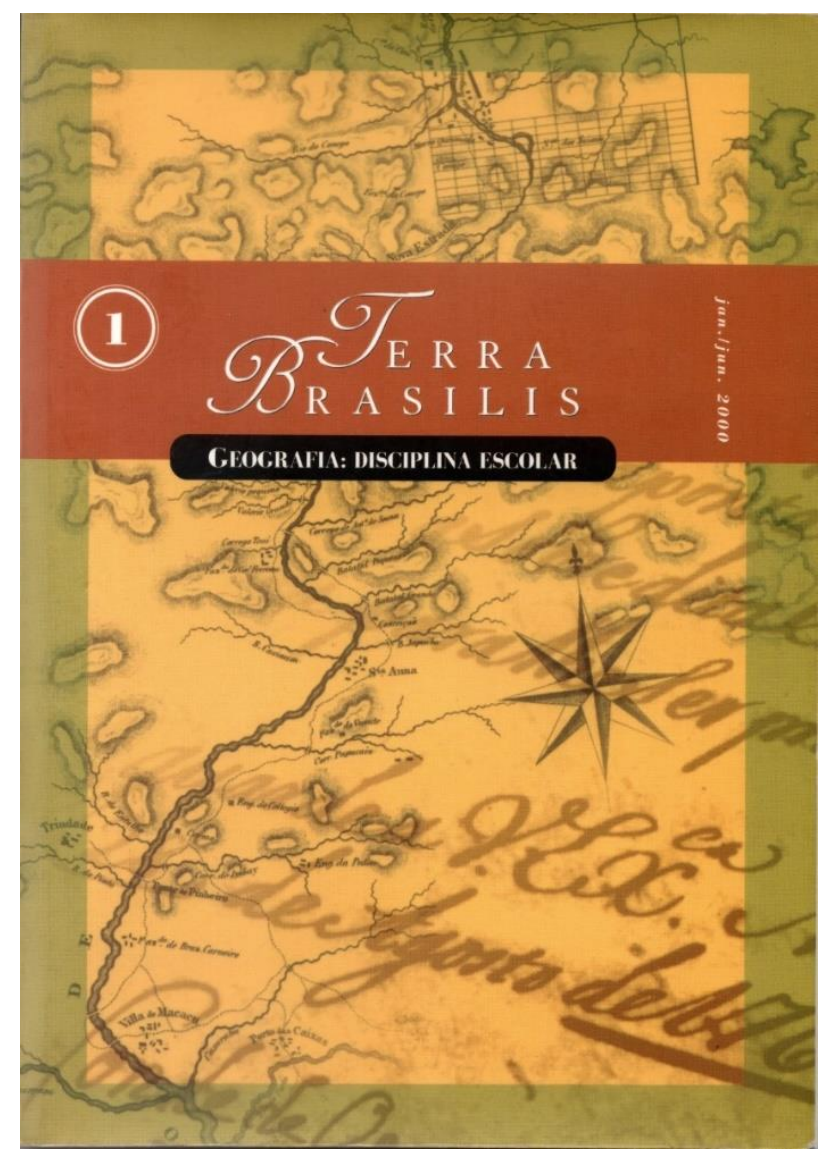

Figura 06: Capa da Revista Terra Brasilis. Jan.-Jun-2000. Fonte: Site da Revista.

A preocupação em vincular História da Ciência e História da Geografia aparecem em muitos dos trabalhos, até mesmo quando a ideia é explorar o diálogo com as artes plásticas, a literatura e os problema teóricos pelos quais transita a Geografia e isso aparece claramente em ensaio publicado em 2008 no Boletim Goiano de Geografia, sob o título Os Ventos do Norte Não Movem Moinhos onde discutimos os novos aportes dos discursos pós-modernos e pós-coloniais para a ciência geográfica.

Os esforços nesse campo de pesquisa se encontram expressos ainda nas aulas que vimos ministrando desde que ingressamos no Programa de Pós-Graduação em Geografia Humana da Universidade de São Paulo, onde oferecemos desde 2008 as seguintes disciplinas: 1) História da Geografia no Brasil: enfoques, temas, periodizações; 2) Abordagens Teóricas e Metodológicas em História da Geografia; 3) Historiografia(s) da Geografia no Brasil e 4) A História da Geografia na Geografia Histórica do Capitalismo..

Há ainda publicações que buscaram, pela periodização e pelos problemas relativos ao campo da história da geografia, investigar as geografias escolares como aquele capitulo de livro publicado em 2011: A Formação e o Exercício Profissional dos 
Professores de Geografia Antes das Institucionalização Universitária no Brasil (18381934).

A terceira linha em que a participação foi importante e decisiva para nossa formação diz respeito a área de Educação, História das Disciplinas Escolares e Ensino de Geografia. Vamos ressaltar aqui em princípio a nossa participação em eventos que nos ajudaram a compreender elementos da Filosofia da Educação e por isso apresentamos comunicação no V Colóquio Internacional da SOFELP (Sociedade de Filosofia da Educação de Língua Portuguesa) intitulado Migrações, Cidadania e Direitos Humanos: um puzzle para a educação? ocorrido em Vila Real em 2016 e onde versamos sobre $\boldsymbol{O}$ Ser no Lugar do Outro: haitianos e bolivianos no Brasil.

Outro evento em que pudemos contribuir como palestrante foi o $12^{\circ} \mathbf{E N P E G ~ - ~}$ Formação, Pesquisa e Práticas Docentes: reformas curriculares em questão, em mesaredonda intitulada História da Geografia Escolar: pesquisa e contribuições para formação de professores, realizada em 2013 na cidade de João Pessoa. Afora isso, como se pode ver viajamos por diversos lugares do País dando conferências e realizando palestras sobre ensino de Geografia entre São Paulo e Teresina, desde Alcântara no Maranhão ao Rio de Janeiro.

A contribuição, nesse campo, que é a Educação e, em particular, a Geografia Escolar sempre representou para nós um imenso prazer.

O nosso artigo mais lido e citado foi publicado no Caderno CEDES em 2005, $\boldsymbol{O}$ Ofício, a Oficina e a Profissão: o lugar social do professor e ali estão explicitados os motivos vários pelos quais optamos em ser professores um dia e continuamos a sê-lo até o fim da nossa existência.

Em parte estas preocupações já haviam sido explicitadas no livro pelo qual tenho o maior carinho de ter escrito Aula de Geografia e Algumas Crônicas publicado em 2003 e reimpresso em cinco mil exemplares em 2008 e já esgotado. Neste livrinho miúdo que gosta de nos habitar o bolso estão crônicas voltadas para fazer transposições didáticas e recontextualizações de conteúdo, mas acima de tudo servem a esse prazer que a Geografia proporciona.

Agora, depois desse périplo de eventos e publicações, gostaríamos de retornar à nossa história na Universidade de São Paulo. Muito bem, foi na USP onde pudemos de fato desenvolver um trabalho que dá lastro às três áreas com as quais trabalhamos de maneira integrada e nos possibilita ensejar agendas de investigação e trabalho.

Trajetórias de Formação em Pesquisa: os encontros com novos mestres e doutores

Estamos na Universidade de São Paulo desde o dia 20 de março de 2007 e ingressamos no Programa de Pós-Graduação em Geografia Humana em 2008, para nesse decênio orientar ao todo 11 teses de doutorado e 13 dissertações de mestrado - Figuras 07 e 08 - que tratam, em larga medida, das mesmas três áreas em que participamos, organizamos, palestramos e publicamos em eventos e periódicos nacionais e internacionais. 


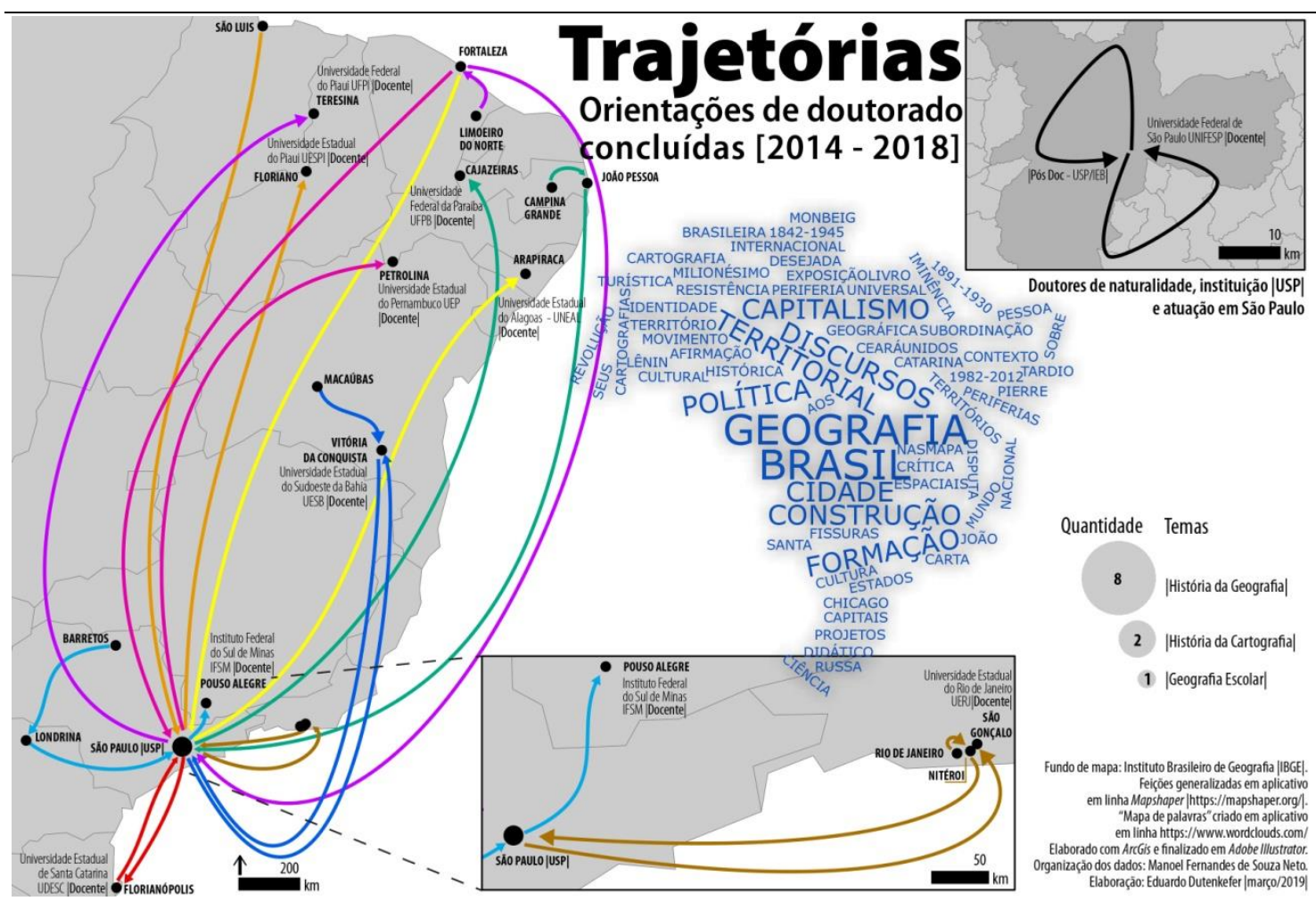

Figura 07: “Mapa Trajetórias - orientações de doutorado concluídas [2014-2018]”. Elaboração: Eduardo Dutenkefer. Organização dos dados: Manoel Fernandes de Sousa Neto.

Gostaríamos agora de dissecar, ainda que de modo breve, como os temas de orientação e a formação que realizamos de quadros docentes em nível de pós-graduação na Universidade de São Paulo, passeiam pela História da Cartografia e Cartografia Histórica, História da Geografia e Geografia Histórica, e pela Educação, História das Disciplinas Escolares e Ensino de Geografia.

A tese de Rildo Borges Duarte com o título Cartografias Capitais: os projetos do Mapa Internacional do Mundo e a Carta do Brasil ao Milionésimo (1891-1930) defendido em outubro de 2018, trata de como o projeto de construção da Carta ao Milionésimo estava dentro de uma lógica de controle do espaço geográfico mundial dirigido pelos centros hegemônicos do capitalismo e, discorre, de modo particular, sobre a participação do Brasil nesse processo ao falar sobre personagens como Francisco Bhering. Por falar em Francisco Bhering foi desse personagem que tratou Rildo Duarte em sua dissertação de mestrado defendida em 2011, também orientada por nós e intitulada Incognitas Geográficas: Francisco Bhering e as Questões Territoriais do Início do Século $\boldsymbol{X X}$, onde buscou compreender diversas polêmicas tratadas por dentro do Clube de Engenharia e outras instituições do Império e da República acerca da melhor maneira de construir um mapa científico do Brasil e que resolvesse várias pendências de limites internos entre unidades do território nacional. Ambos os trabalhos se afinam com toda uma literatura em torno da história da cartografia e da cartografia histórica.

A tese de Larissa Alves de Lira, Pierre Monbeig e a Formação da Geografia Brasileira: uma ciência no contexto do capitalismo tardio, foi defendida em 2017 e teve além de nossa orientação uma co-orientação em co-tutela com Marie-Vic OzoufMarignier da École des Hautes Études en Sciences Sociales, França. O trabalho longo e magistral busca entender como Pierre Monbeig desenvolve, aprimora e cria métodos em Geografia a partir de sua herança de formação vidaliana em um país tropical, continental e de capitalismo tardio como o Brasil. O trabalho doutoral de Larissa Lira, foi, certo modo, uma continuação de suas preocupações acerca do método na longa tradição 
francesa e partiu de sua dissertação de mestrado, também realizada sob nossa orientação e defendida em 2012 com o título O Primeiro Esboço do Método Geográfico de Vidal de la Blache a partir dos estudos do Mediterrâneo: permanências e rupturas no contexto da Institucionalização da Geografia (1872-1918). A dissertação, de fato, longamente respaldada sobre a questão do método em Vidal de La Blache, traz como tese central a ideia de que Fernand Braudel desenvolveu boa parte de sua geohistória a partir dos estudos e método de Vidal e tece de maneira muito competente aspectos centrais da geografia lablachiana que derivam da discussão sobre circulação, adaptação, região geográfica, gêneros e modos de vida, identidades regionais.

Ambos os trabalhos de mestrado de Larissa Lira e Rildo Duarte foram publicados pela Alameda Casa Editorial, com financiamento FAPESP e integrando o que pretendíamos fosse uma coleção ainda maior denominada História(s) da Geografia.

Já a tese de Erivaldo Costa de Oliveira, A Geografia de Lênin na Revolução Russa, defendida em fevereiro de 2017, busca compreender como nas obras do pensador russo aparecem problemas que são centrais à compreensão das questões geográficas e nodais à constituição do processo revolucionário de 1917. A tese analisou temas como população, circulação, urbanização e economia no processo de formação territorial russo para extrair daí a leitura leninista sobre geografia e revolução. O tema que buscava estabelecer uma agenda de pesquisa para a geografia das revoluções se esboçara já em sua dissertação de mestrado, também orientada por nós e defendida em 2012 sob o título de As Territorialidade Sovietes da Revolução Russa (1905-1921), onde Erivaldo Costa constrói uma espécie de atlas em anamorfose que identifica como a revolução foi se dando da periferia russa em direção aos centros urbanos, ali onde a revolução eclodiu naqueles dez dias que abalaram o mundo.

Ainda sobre história do território e formação territorial podemos falar das teses de Ana Maria Albuquerque, Territórios em Disputa: a formação territorial do Ceará de 1750 a 1822, defendida em 2017 e de André Souza Martinello, Geografia Histórica, discursos espaciais e construção territorial de Santa Catarina, defendida em 2015. Ambos os trabalhos abordam o processo de formação territorial e estão fortemente embasados nas contribuições teóricas de Antonio Carlos Robert Moraes. Assim apesar de tratarem de diferentes momentos da história da formação territorial e de territórios distintos, o fazem sob as mesmas chaves de entendimento teórico de compreender que as formações sociais se dão mediante os processos de valorização do espaço e apropriação do território.

A história da geografia no processo de formação territorial é, por outro lado, desenvolvida de maneira primorosa e arguta por Raimundo Jucier de Sousa Assis em sua tese doutoral defendida sob nossa orientação em 2017. O tema da investigação muito estudado pelos historiadores, no caso as Exposições Universais, ganha na tese intitulada A Iminência da Subordinação aos Estados Unidos: a afirmação do Brasil como periferia do capitalismo na Exposição Universal de Chicago, uma outra leitura crítica. O mais importante é como o tema pode ser apropriado pela história da geografia, compreendida ai a própria tessitura das geografia mundial pelo capitalismo naquele momento da formação de uma sistema-mundo em fins do século XIX. Além de um belo texto, a tese revela uma excelente discussão de método.

É no âmbito de uma tessitura marcadamente de critica marxista que a tese de Sócrates Oliveira Menezes, defendida sob nossa orientação em 2015 faz, vestida com o título de $\boldsymbol{O}$ Trabalho nas Fissuras do Crítica Geográfica, uma análise arguta de como a geografia crítica ou radical no Brasil fez um movimento incompleto, ao não propor sua própria autocrítica e sucumbiu assim ao canto de sereia das novas epistemologias. 
As cidades e suas pulsões e conflitos aparecem ainda nos movimentos e representações que delas se faz, um pouco para contar a história urbana a partir das perspectivas das formações periféricas ou das cartografias turísticas. Aqui fazemos menção a duas teses que tivemos imenso prazer em orientar. A primeira de Silvia Lopes Raimundo, Território, Cultura e Política: movimento cultural das periferias, resistência e cidade desejada, defendida em 2017 e a segunda de Mônica Maria Ferreira Teles, A Cartografia Turística de João Pessoa e seus discursos sobre a Cidade, que veio a luz em 2015. A primeira tese, de Silvia Raimundo analisa como os coletivos de cultura se formam a partir da própria urbanização de São Paulo e como resposta a ausência de equipamentos e políticas para os trabalhadores, majoritariamente negros, que recriam a cidade em meio à música, teatro, literatura e atividades culturais que reclamam políticas diversas e o direito à cidade. A segunda tese, de Mônica Telles, constrói um acervo histórico de mapas turísticos que vendem uma João Pessoa criada a partir de representações idílicas da cidade e negadoras dos seus diversos usos pelos seus habitantes.

A primeira das teses que orientamos Geografia Política e Geopolítica no Brasil (1982- 2012), foi defendida por Eduardo Karol em 2014. O trabalho versa sobre o pensamento geopolítico brasileiro de geógrafos e geógrafas do Brasil, tratando de maneira mais amiúde da obra mais vasta no tema que é da autoria de Bertha Becker.

É possível antever que se entrelaçam nos trabalhos de tese orientados por nós temas que discorrem sobre História da Geografia, Geografia Histórica, História da Cartografia e Cartografia Histórica a partir de diferentes escalas espaço-temporais, geralmente referenciadas em teorias e métodos vinculados à certa tradição geo-histórica ou da geografia crítica ou ainda relativas à nova história da cartografia.

Bem, vamos as dissertações que, em muito, trataram de personagens envoltos em seus contextos, não raro a partir das apropriações de método propostas por Vincent Berdoulay e envoltos em uma estreita relação com os aportes propostos pela Science Studies.

A começar pela dissertação de Alexandre Henrique da Silva Santos, defendida recentemente em setembro de 2018, Organizando a Terra: Nicolas Demarest e o Verbete Geografia Física na Enciclopédia de Diderot e D'Alembert que trata, a partir de um personagem das polêmicas entre vulcanismo e plutonismo na origem da terra, para pensar os vínculos dessa geografia nascida da geologia como se podia arquitetar naquela França de muitas transformações históricas, políticas relativas à produção agrícola. No centro, é claro, uma bela história da ciência que vai desde os Salóes e Cafés Filosóficos às Sociedades Savants e se expressa em obras monumentais erigidas pela razão iluminista como a Enciclopédia.

Um outro personagem, quiçá menos nobre, dirá muito mais interessante do ponto de vista literário, foi o que revelou a dissertação de Giulliano Coutinho defendida também em 2018, Mário de Andrade e as Ideologias Geográficas - entidade e território em Macunaíma- o herói sem nenhum caráter. Ai aparecem claramente as ilações entre literatura modernista e a construção de um personagem que encarna, aquilo que Antonio Cândido identifica como uma certa Dialética da Malandragem na formação cultural brasileira. O trabalho, além de atualizar o debate sobre ideologias geográficas é delicioso de ler.

Outro belíssimo trabalho, agora vinculando cinema, paisagem e geografia histórica é aquele defendido em 2012 por Renato Alves do Nascimento, A Paisagem Narrativa do Nordeste e dos Nordestinos nos Filmes de Vladimir Carvalho. O texto analisa três documentários sobre a Paraíba, dentre eles o País de São Saruê, onde faz 
uma espécie de geografia histórica retrospectiva a partir das transformações paisagísticas e sobre os ombros de Ana Francisca Azevedo e seu belo livro A Idéia de Paisagem.

Ainda que não tão literários, outros três trabalhos de mestrado, dissertam sobre o cruzamento entre história da geografia e formação territorial. São eles os escritos de: Marcel di Angelis Souza Sandes, A Natureza da Geografia: nos meandros da História defendido em 2015 e que trata da formação do pragmatismo filosófico estadunidense no processo de consolidação do Meio Oeste Americano e do pensamento geográfico de Richard Hartshorne. A investigação de Carlos Henrique Silva defendida em 2014, O Pará aos Pedaços: projetos de criação dos estados de Carajás e Tapajós, que versa sobre os discursos relativos à criação de novas unidades federativas a partir de argumentos eminentemente geográficos. A pesquisa de Silvia Maria Tomasini, defendida em 2012, A Metrópole e seus Aeroportos: o caso do Campo de Marte, onde discorre a partir de vasta documentação acerca do conflito entre entes confederados como município, estado e união no que diz respeito aquela área considerada como rossio e vinculado à longa tradição urbana lusitana.

Duas investigações distintas no campo da Educação, História das Disciplinas Escolares e Ensino de Geografia, são as dissertações de Murilo Rossi, A Nova Proposta Curricular do Ensino de Geografia da Rede Pública de São Paulo: um estudo defendida em 2011, trata do uso das cartilhas para a aplicação de uma geografia vinculada à pedagogia das competências. A outra dissertação é de Maria Ediney Ferreira da Silva, defendida em 2012 sob o título $\boldsymbol{O}$ Nordeste nos Livros Didáticos de Geografia (19051950), trabalho em que analisa como a região depois tratada como Nordeste a partir de 1937 aparecia antes dessa sua designação realizada pelo Estado. Ao mesmo tempo, é de Maria Ediney a última tese defendida sob nossa orientação em 2018 e que dando continuidade a pesquisa iniciado no mestrado, trata $\boldsymbol{A}$ Construção da Identidade Nacional no Livro didático de Geografia (1842-1945)

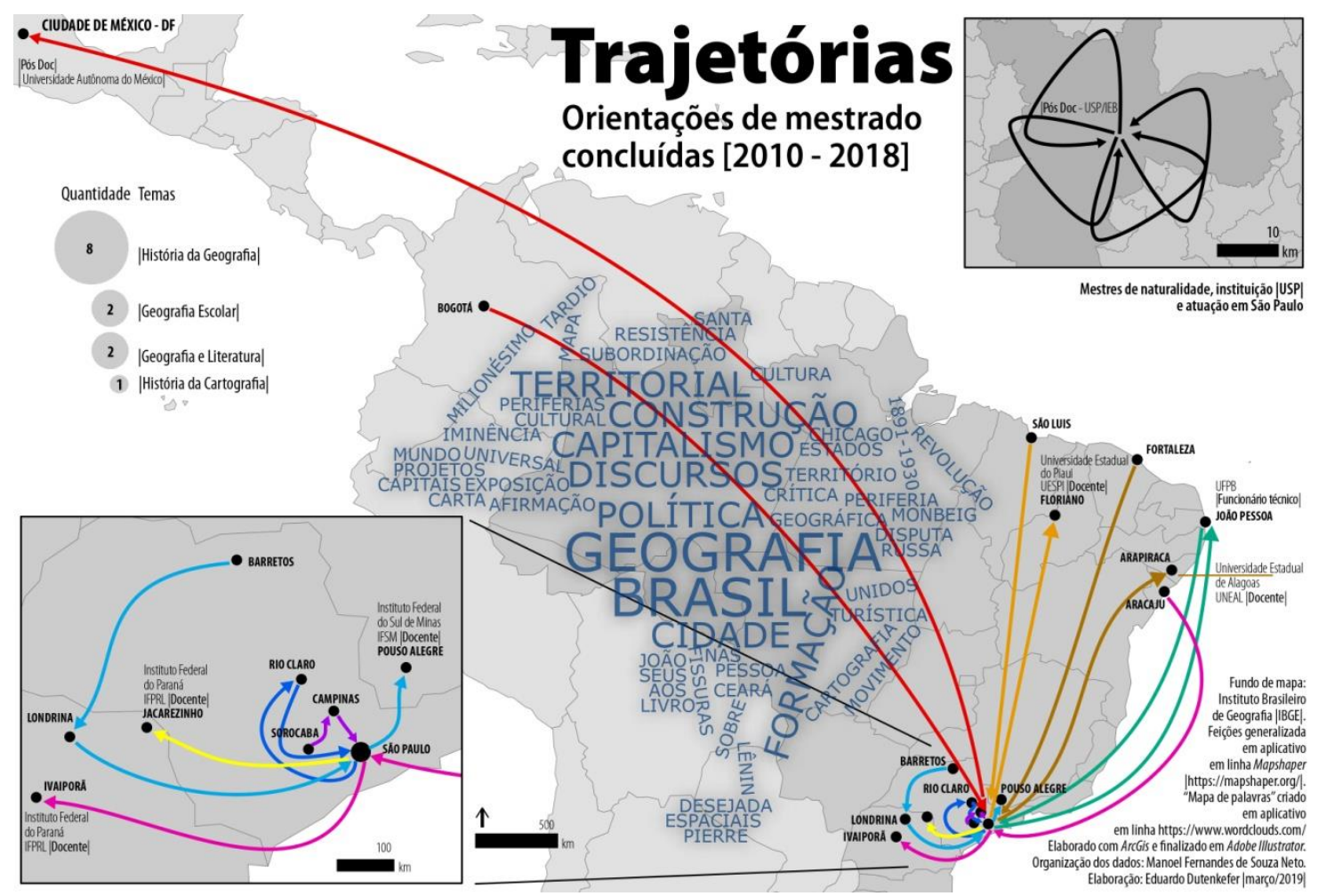

Figura 08: "Mapa Trajetórias - Orientações de Mestrado concluídas [2010-2018]. Elaboração: Eduardo Dutenkefer. Organização dos dados: Manoel Fernandes de Sousa Neto. 
Por fim, ou para falar de começos, as duas primeiras dissertações por nós orientadas dialogam com as leituras feitas por Élisée Reclus sobre a Colômbia e o Brasil. A primeira dissertação defendida em 2010 é de David Alejandro Ramirez Palacios, Élisée Reclus e a Geografia da Colômbia: cartografias de uma intersecção e o segundo de Marcelo Augusto Mihahiro, defendido em 2011, O Brasil de Élisée Reclus: território e sociedade em fins do século XIX. Ambos os trabalhos versam sobre as leituras reclusianas e sua Geografia Universal acerca desses dois países e, sempre, a partir de uma ampla correspondência e atividades mais longas ou breves do anarquista francês nesses dois países, seus contatos e influências que recebeu e deixou.

Por último iniciamos a partir de 2017 algumas supervisões de pós-doc e tivemos a felicidade de acompanhar o estágio de Larissa Alves de Lira que desenvolveu suas pesquisas com bolsa PNPD e teve como tema um problema de geo-história: No Terreno da Conquista. Natureza, Técnica e a Escolha da Localização de Brasília (1941-1955). A outra investigação pós-doutoral, também vinculada a área de geo-história foi da Professora da Universidade Federal do Acre, Maria Jesus de Morais que entre 2017 e 2018 investigou a produção de borracha na Amazônia com trabalho intitulado Seringa, Siringa e Caucho - seringueiro, siringales e caucheiros: os dito e não-ditos sobre o processo de colonização da Pan-Amazônia nos Institutos Históricos e Sociedades de Geografia do Rio de Janeiro e de La Paz. E, por fim, mas não menos importante, supervisionamos no mesmo período o Professor Paulo Roberto Teixeira de Godoy, colega da UNESP-RC, com a pesquisa A Valorização Capitalista do Espaço sob a Perspectiva da Teoria Marxista do Valor, que apresenta pesquisa teórica de extrema importância para a compreensão da geografia histórica.

As atividades de orientação deixam antever como investigações comuns foram se cruzando para desenhar um interessante campo de reflexões a apropriações teóricas em torno dos temas acerca do quais já discorremos em momento anterior e versam sobre a relação inextrincável entre a história da geografia, história da cartografia e educação em geografia e claro, seus diálogos com geografia histórica em diferentes escalas espaçotemporais.

É quiçá por cruzar vários campos do conhecimento nas nossas preocupações e diálogos que tenhamos participado de bancas de mestrado e doutorado em diversas instituições do País (Figura 09), para avaliar trabalhos defendidos na Filosofia, Linguística, Educação, História e Arquitetura, bem como para encontrar diversos modos de conceber e fazer geografia em diversos quadrantes do Brasil. 


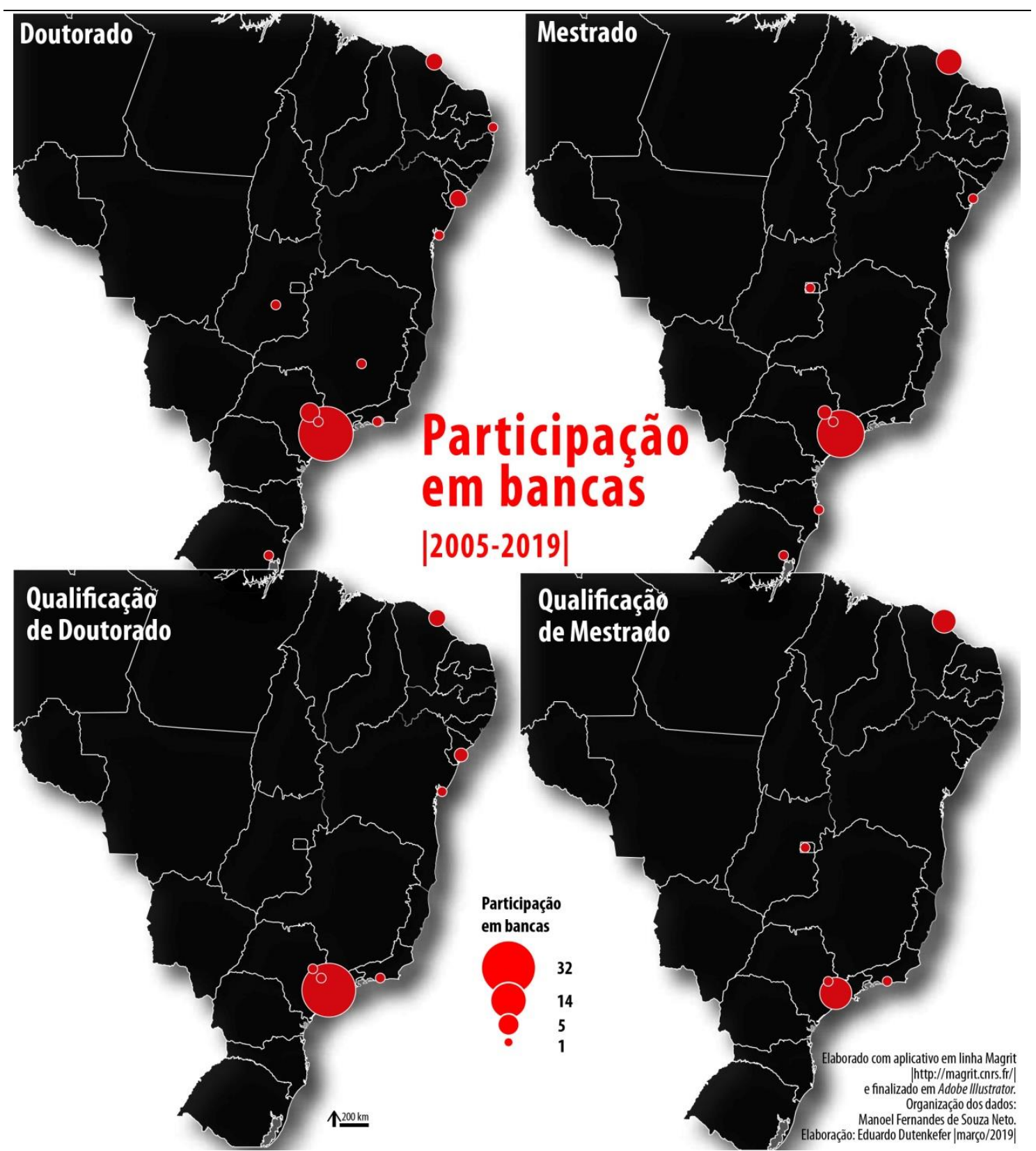

Figura 09: Mapa de Participação em Bancas [2005-2019]. Elaboração: Eduardo Dutenkefer. Organização dos dados: Manoel Fernandes de Sousa Neto.

Vale ressaltar ainda que nosso trabalho na USP resultou na orientação de diversos trabalhos finais de graduação e orientações de iniciação científica, somadas aquelas já realizadas na UFPB e UFC.

Por fim, mas não menos importante, ministramos nos cursos de Graduação da Universidade de São Paulo disciplinas como História do Pensamento Geográfico, Teoria e Método em Geografia I, Teoria e Método em Geografia II, Geografia Política e Geografia Humana e Econômica para o Curso de História..

Por outro lado, as lides nas salas de graduação e pós-graduação, sempre contaram com expressivo número de estudantes e, ainda que com turmas lotadas muitos matriculados, o aproveitamento sempre foi elevado. 


\section{Gráfico: Quantitativo de alunos matriculados e aprovados/concluintes na} Graduação e Pós-Graduação (2007* - 2018)

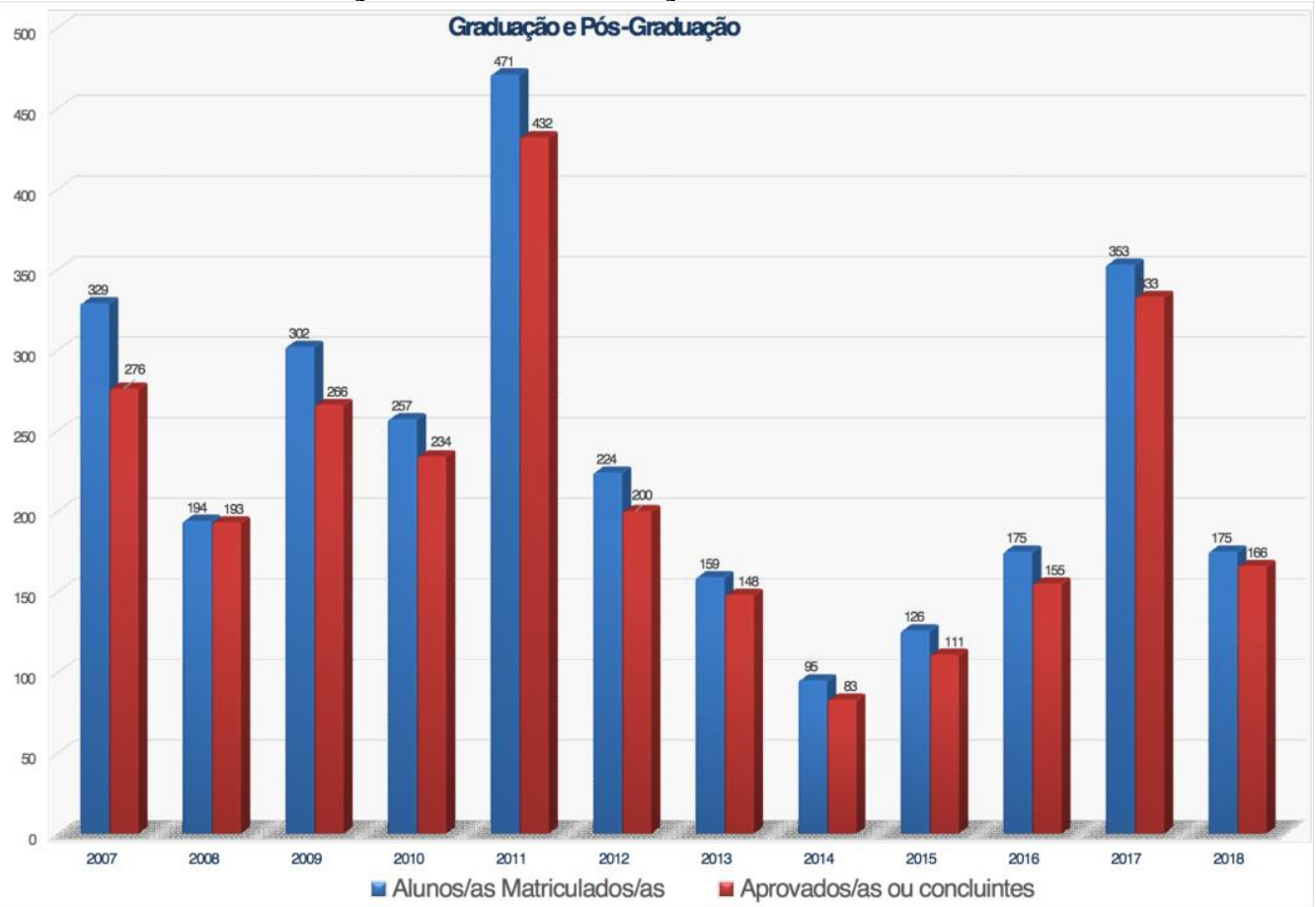

Gráfico 01: Quantidade de alunos/as matriculados/as e de alunos/as concluintes. Fonte: Sistema.usp.br Organização dos dados: Manoel Fernandes de Sousa Neto.

O percurso formativo que fizemos nos permite propor que nos formamos ao longo de toda esta série de encontros com outras áreas do conhecimento, o que nos garantiu geralmente olhar a Geografia a partir dos diálogos que ela poderia fazer e jamais como sendo uma disciplina acadêmica justificável em si mesma.

Um Mapa Disperso das Palavras Impressas em meio a alguma poesia: breviário das últimas publicações e dos Próximos Passos

Ainda somos apaixonados por livros de papel e por folhear de maneira avulsa as palavras, mesmo quando a lide é de pesquisa, esta vivência para com o ócio das imagens que os vocábulos anunciam é uma prática corrente.

Nos últimos tempos nos tem preocupado questões relativas ao modo como as métricas tem dominado o processo de realização da ciência e, em particular da geografia, e a desconstrução do tempo lento, da reflexão de largo curso e da criação daquilo que Bruno Latour nomeou como conformação de centros de cálculo.

Este debate nos acompanha em três publicações, a primeira delas realizada em 2017 na Revista da ANPEGE em artigo intitulado A Expansão Financeirizada do Ensino Superior e da Pós-Graduação no Brasil. A segunda em capítulo de livro publicado em 2016, também resultado de atividade de mesa realizada no ENANPEGE de 2015, sob o título Queime Depois de Ler, onde avaliamos como os processos de ranqueamento dos periódicos tem se transformado em um negócio lucrativo, ao mesmo tempo estabelecem parâmetros eurocêntricos e anglófonos de legitimação do que é válido e do que não é em termos de teorias, métodos, problemas e temas de investigação em uma perspectiva de colonização dos saberes. O terceiro, resultado inicial de uma fala na 
comemoração dos 30 anos do Programa de Pós-Graduação em Geografia da Universidade de Sergipe, foi publicado na Revista Geonordeste e integra o conjunto de reflexões que temos feito sobre produção, circulação e apropriação do conhecimento em nossa área foi publicado em 2014 e intitula-se Breve Ensaio em Memória dos Números da PósGraduação em Geografia no Brasil.

A travessia em torno daquilo que escrevemos se encontra impresso ainda em artigos de jornal, prefácios de livros, resenhas e tudo isso faz parte de uma construção que agora desagua naquilo que considero ser o trabalho intelectual desse um quarto de século de jornada na Universidade Pública no Brasil.

Em meio as escritas mais duras e as lutas mais árduas resolvemos publicar um livro de poemas, o Nó Frágil em 2018, para dizer que a sobrevivência na lide acadêmica não pode prescindir da poesia, já que só a poesia salva.

\section{Notas}

1 - Na Universidade de São Paulo as vagas para ingresso na carreira docente são denominadas e conhecidas na linguagem corrente como claros. Aqui fica o nosso registro ao preconceito racial que aparece na denominação.

2 - “... a reitoria comandada por Marco Antônio Zago desenvolve, desde o ano passado, um conjunto de ações que apontam para uma reestruturação radical da função docente na maior universidade do país. Começou com Zago dando depoimentos à revista Veja e ao Estadão, nos quais propunha diminuir a quantidade de docentes em dedicação exclusiva à Universidade, qualificando essa integralidade como uma limitação para o gestor eficiente e qualificando-a como uma "jabuticaba brasileira"." In: "Coagindo o Saber: iminência na USP, ameaça para todos. Por Adrián Pablo Fanjul. Portal Carta Maior em 06 de novembro de 2015. https://www.cartamaior.com.br/?/Editoria/Idades-da-Vida/Coagindo-o-saberIminencia-na-USP-ameaca-para-todos/13/34921, acesso em 06 de novembro de 2019.

3 - Jornal Estado de São Paulo. "USP contrata consultoria privada para discutir novo modelo de gestão", por Luis Fernando Toled. Em 21 de Setembro de 2016. https://educacao.estadao.com.br/noticias/geral,uspcontrata-consultoria-privada-para-discutir-novo-modelo-de-gestao,10000077364, acesso em 06 de novembro de 2019.

4 - Outras Palavras, "USP: o que a reitoria (e a repressão) tentam esconder." Por Maria Caramez Carlotto em 13 de Março de 2017. https://outraspalavras.net/sem-categoria/usp-o-que-a-reitoria-e-a-repressaotentam-esconder/, acesso em 26 de novembro de 2019. 